\title{
Wpływ koncepcji sprawiedliwości Chaima Perelmana na dokonywane dzisiaj rozstrzygnięcia Trybunału Konstytucyjnego
}

\section{Wstęp}

stota „sprawiedliwości” była przedmiotem rozważań wielu myślicieli na przestrzeni wieków. Wieloznaczność wyrazu, różnica w pojmowaniu1, wielość pojęć oraz "uczuciowy rezonans" ${ }^{2}$, jak również obszerna i skomplikowana literatura zagadnienia przysparzają kłopotów w zrozumieniu tego, co nazywamy „sprawiedliwością". O istocie tego pojęcia mowa jest już w dziełach Platona i Arystotelesa $a^{3}$; spory dotyczące sprawiedliwości przez wieki nie straciły na aktualności ${ }^{4}$.

* Mgr Piotr Szymon Śmieja - doktorant na Wydziale Prawa i Administracji Uniwersytetu Śląskiego w Katowicach, e-mail: piotr.smieja@op.pl, ORCID 0000-0002-9822-8083.

${ }^{1}$ Por. Z. Ziembiński, O pojmowaniu sprawiedliwości, Lublin 1992, s. 16: „Nie idzie zatem [...] jedynie o spory werbalne, ale o merytoryczne spory moralne czy polityczne, przesłonięte sporami o definicję sprawiedliwości. Spotykamy w tej dziedzinie klasyczne przykłady posługiwania się definicjami perswazyjnymi".

${ }^{2}$ K. Ajdukiewicz, O sprawiedliwości, „Kultura i Wychowanie” 1939, nr 2, s. 365.

${ }^{3} \mathrm{H}$. Kelsen, The Metamorphoses of the Idea of Justice, w: Interpretations of Modern Legal Philosophies. „New York Times” 1 stycznia 1947, s. 389-399 (cyt. za: S. Biernat, Rozdział dóbr przez państwo. Uwarunkowania społeczne i konstrukcje prawne, Wrocław 1989, s. 61; cyt. za: S. Tkacz, Rozumienie sprawiedliwości w orzecznictwie Trybunału Konstytucyjnego, Katowice 2003, s. 29).

${ }^{4}$ Z. Ziembiński, O pojmowaniu..., s. 15: „Ładunek emocjonalny słowa "sprawiedliwość« związany jest z tym, że o sprawiedliwość toczą się wojny; że w imię tak czy inaczej pojmowanej sprawiedliwości wybuchają rewolucje, skazuje się ludzi, pozbawia się jakichś dóbr jednych i przyznaje je innym, przyznaje się i odbiera przywileje (cyt. za Ch. Perelmanem). Ludzie gotowi są znosić wiele, byleby te ciężary były sprawiedliwe [rozkładane], a czują się pokrzywdzeni, jeśli powodzi się im nieźle, ale gdy innym powodzi się niesprawiedliwie lepiej”. 
W tym artykule przybliżam teoretyczny model sprawiedliwości zaproponowany przez logika i filozofa prawa ${ }^{5}$ Chaima Perelmana ${ }^{6}$. Zwracam uwage na jego badania, gdyż są próbą uporządkowania wiedzy o działalności prawników w zakresie wymierzania sprawiedliwości, a także spojrzeniem na pojęcie sprawiedliwości z punktu widzenia analizy logicznej.

Poniżej przedstawię rozważania Perelmana dotyczące trudności w zbudowaniu spójnej definicji pojęcia sprawiedliwości, opierając się kolejno o jego koncepcję rozumienia terminu ${ }^{7}$ „sprawiedliwość” oraz konstrukcję tzw. „formuł sprawiedliwości”. Dalej zwrócę uwagę na podmioty, między którymi można operować pojęciem sprawiedliwości, a także na te aspekty teorii Perelmana, które nawiązują do prawości sędziego. Zarysuję także część dorobku naukowego badacza, która nadal jest przedmiotem zainteresowania prawników i filozofów.

Zaproponowane przez Perelmana formuły, sugerujące komu i według jakich zasad przyznać „coś”, są sposobem, w jaki podjąć można działanie w ramach sprawiedliwości. Uczony zdaje sobie jednak sprawę, że takie ujęcie jest niedoskonałe (formuły nie są bowiem gotowym wzorcem) i pozostawia ostateczną decyzję „prawości sędziego”. To pojęcie nie jest jednak przez niego zdefiniowane. Słownik Języka Polskiego ${ }^{8}$ tłumaczy „prawość” jako „charakter człowieka prawego, szlachetność, uczciwość, cnotliwość”; dawniej rozumiano je raczej jako „zgodność z prawem, prawomocność, legalność” lub też „prawdziwość” i „słuszność, sprawiedliwość”. Znaczenie „prawości” (a tym bardziej „prawości sędziego") nie jest zatem ani jednorodne, ani oczywiste, i wymaga szerszego zbadania w osobnej publikacji. Stawiam jednak tezę, że Perelman przez wyrażenie „prawość sędziego” rozumie tę cechę, którą sprawiedliwy sędzia powinien się kierować, gdy do podjęcia słusznej decyzji nie wystarczają istniejące formuły. W tym sensie „prawość sędziego” ma znaczenie zasadnicze i powoływanie się na nią jest czynem pożądanym. Przeprowadzone niżej rozważania pomogą zrozu-

${ }^{5}$ Zob. Ch. Perelman, O sprawiedliwości, przeł. W. Bieńkowska, Warszawa 1959, s. 7 i nast. W 1938 Perelman otrzymał doktorat $\mathrm{z}$ filozofii na podstawie pracy poświęconej niemieckiemu matematykowi, logikowi i filozofowi Gottlobowi Fregemu. Zainteresowanie badacza logiką i etyką stopiło się w nową retorykę, a w konsekwencji - w logikę wartościowania pragnącą uchwycić mechanizm ludzkiego myślenia. Fakt ten jest nie bez znaczenia dla sformułowanej przez Perelmana koncepcji sprawiedliwości.

${ }^{6}$ Model ten został przedstawiony w 1945 roku w publikacji Perelmana pod tytułem De la justice, natomiast polski przekład Wiery Bieńkowskiej ukazał się w 1959 roku.

7 Zob. Z. Ziembiński, Sprawiedliwość społeczna jako pojęcie prawne, Warszawa 1996, s. 7: „Słowo »termin « jest związane z tradycyjną logiką i oznacza podmiot lub orzecznik zdania oznajmującego o budowie podmiotowo-orzecznikowej. Ogólniej oznacza ono nazwę jakiejś osoby lub przedmiotu (nazwy konkretne), ale też jakichś stanów rzeczy, zdarzeń, stosunków albo cech rozpatrywanych in abstracto".

${ }^{8}$ Zob. Prawość, w: Słownik Języka Polskiego. red. W. Doroszewski, online: https://sjp.pwn.pl/ doroszewski/prawosc;5481278.html [dostęp: 6 sierpnia 2020]. 
mieć trudności związane z analizą orzeczeń, w których Trybunał Konstytucyjny powołuje się wprost na teorię sprawiedliwości Perelmana lub do niej nawiązuje.

\section{Próby zdefiniowania sprawiedliwości przez Perelmana}

Poszukiwania Perelmana były nakierowane na problem odniesienia ,sfery wartości do nauk ścisłych"`. Badacz uważał, że popełnia się błąd podwójnej definicji, gdy zaproponowane określenie łączy się z jego znaczeniem emocjonalnym. Takie działanie skutkuje zawarciem wartości w przedmiocie definicji, co nadaje jej pewne znaczenie. Definiowanie jakiegoś wyrażenia nie powinno mieć charakteru arbitralnego, a w konsekwencji oceniającego, ponieważ w ten sposób burzymy neutralność poznania naukowego ${ }^{10}$.

Autorka publikacji dotyczącej Perelmana, Joanna Kiereś-Łach, twierdzi, że jego działania są próbą definicji sprawozdawczej lub deskryptywnej, która informuje o licznych funkcjach semiotycznych i jest wolna od ładun$\mathrm{ku}$ emocjonalnego. Choć takie podejście również ma charakter arbitralny (zdaje bowiem sprawę z tego, co istnieje, ale nie określa wszystkich możliwych sposobów użycia terminu), to jednak jest ono najbardziej analityczne. W przeciwnym razie mówimy nie o definicji, lecz o sądzie syntetycznym.

Jak zauważa badaczka, natura powyższego zadania jest zupełnie inna niż w przypadku nauk ścisłych. Konsekwencją tej dwoistości jest niemożność zbudowania spójnego logicznie systemu myślowego (kluczowe terminy społeczne zawsze nacechowane są emocjonalnie lub odnoszą się do najwyższych wartości)" ${ }^{11}$ Następnie wskazuje, że niejasność jest cechą immanentną terminów zabarwionych emocjonalnie, a - jak pisze Perelman - „zadaniem filozofii jest systematyczne badanie pojęć mglistych”ı. Trafnie ujmuje to inna badaczka teorii sprawiedliwości, Maria Ossowska: „ktokolwiek definiował dotąd sprawiedliwość mniemając, że właśnie ową sprawiedliwość w ogóle definiował, zawsze w gruncie rzeczy definiował jakąś jej konkretną odmianę" ". Jeżeli każdy, kto pojmuje sprawiedliwość na swój sposób, próbowałby taki obraz za wszelką cenę narzucić innym, doszłoby do pomieszania pojęć; $z$ drugiej strony, nie ma możliwości, aby zgromadzić każdy sens słowa „sprawiedliwość”, zbudować jedną spójną

${ }^{9}$ J. Kiereś-Łach, Filozofia i retoryka. Kontekst myślowy „nowej retoryki” Chaïma Perelmana, Lublin 2015, s. 29.

${ }^{10}$ Ch. Perelman, O sprawiedliwości..., s. 16.

${ }^{11}$ J. Kiereś-Łach, Filozofia..., s. 42.

${ }^{12}$ Ch. Perelman, O sprawiedliwości..., s. 18; cyt. za: J. Kiereś-Łach: Filozofia..., s. 29.

${ }_{13}$ M. Ossowska, Ch. Perelman - O sprawiedliwości (De la justice), [w:] „Ruch Filozoficzny” 1948, nr 3-4, s. 126 i n. 
definicję i jej użyćlit (niemalże na sposób matematyczny - podstawiając dane do wzoru). Perelman systematyzuje pojęcia sprawiedliwości najczęściej używane i najbardziej popularne, by zmniejszyć nieporozumienia w praktycznym obszarze stosowania tego pojęcia'

Perelmanowska definicja sprawiedliwości formalnej pojawia się mniej lub bardziej bezpośrednio $\mathrm{w}$ jego dziełach odnoszących się do retoryki i zawsze jawi się jako trzon systemu myślowego autora ${ }^{16}$.

\section{Trzy komponenty teorii sprawiedliwości Perelmana}

Perelman zwraca uwagę, że ,[...] świat nie sprowadza się do tautologii, do zwykłego rozwoju zasady tożsamości”ı , lecz odwrotnie: zawsze istnieje pewne niedopowiedzenie. Najogólniejsze prawa nauki pozwalają wyjaśnić poszczególne prawa różnych dziedzin, ale same pozostają niewyjaśnione ${ }^{18}$. Inaczej ma się sytuacja w systemie normatywnym: zakładamy istnienie pewnej wartości najbardziej ogólnej, z której wynikają różne normy, ,a wartość ta nie ma podstaw ani w logice, ani w rzeczywistości" ${ }^{19}$. Ta uwaga może wyjaśniać istnienie wielu systemów sprawiedliwości wspartych na różnych wartościach, a co za tym idzie - może istnieć taka liczba formuł prawnych, jaka jest liczba wartości arbitralnych (tzn. niepewnych). Według Perelmana ten fakt jest pierwszym komponentem sprawiedliwości, mianowicie: szukamy wartości, która tworzy sprawiedliwość.

Drugim elementem teorii sprawiedliwości Perelmana jest prawidło, które określa sprawiedliwość. Należy przez nie rozumieć imperatyw (uniwersalny dla wszystkich rodzajów sprawiedliwości wynikającej z różnych wartości), który brzmi: „traktować w pewien sposób wszystkie istoty należące do określonej kategorii" ${ }^{20}$. Innymi słowy prawidło sprawiedliwości formalnej jest wspólnym pierwiastkiem wszystkich koncepcji sprawiedliwości konkretnej, czyli takiej, która wynika z danej wartości i traktuje ją jako swój ideał ${ }^{21}$. Prawidło nie jest arbitralne, jednak może się takim stać, gdy nie znajduje uzasadnienia ${ }^{22}$.

\footnotetext{
14 J. Kiereś-Łach: Filozofia..., s. 43 i nast.

15 Tamże, s. 45.

16 Tamże, s. 71 (w przypisach autorka przywołuje dokładnie porównywane dzieła).

17 Ch. Perelman, O sprawiedliwości..., s. 97.

18 Tamże.

19 Tamże.

20 Tamże, s. 77.

21 Tamże, s. 78.

22 Tamże, s. 94.
} 
Trzecim komponentem teorii sprawiedliwości Perelmana jest czyn, który urzeczywistnia sprawiedliwość. Perelman konkluduje, że „każdy system sprawiedliwości powinien pamiętać o swojej niedoskonałości i wyciągnąć z niego wniosek, że niedoskonała sprawiedliwość, bez miłosierdzia nie jest sprawiedliwością" ${ }_{23}$.

Nawiązując do poglądów Immanuela Kanta, Kiereś-Łach stwierdza, że „sprawiedliwość jest przejawem rozumu praktycznego"24, (to jest rozumu w działaniu), efektem , chłodnego i racjonalnego namysłu opartego na uniwersalnych zasadach" ${ }^{25}$, a nie oceny dokonanej pod wpływem emocji. By móc zastosować sprawiedliwość, w pierwszej kolejności należy przybrać rozważaną rzeczywistość w istotne dla danej sytuacji kategorie. Innymi słowy konieczne staje się zaklasyfikowanie omawianego przypadku do grupy takich samych lub podobnych pzypadków. Szczególną uwagę należy tu zwrócić na niemożność zastosowania sprawiedliwości bez prawideł, bez korzystania z pewnego systemu ${ }^{26}$.

\section{Budowa formuł sprawiedliwości Perelmana. Rodzaje kategorii istotnych}

W swojej pracy O sprawiedliwości Perelman wyszczególnił sześć formuł sprawiedliwości, dla których szukał „swego rodzaju wspólnego mianownika, różnią się tym, że każda z nich uważa inną cechę charakterystyczną za jedyną, jaką należy brać pod uwagę w stosowaniu sprawiedliwości, i tym, że określają w inny sposób przynależności do tej samej kategorii istotnej. Zawierają także mniej albo bardziej dokładne wskazówki co do sposobu, w jaki należy traktować członków tej samej kategorii istotnej" ${ }^{27}$.

Omawiane wyżej prawidło oznacza sprawiedliwość formalną ${ }^{28}$, natomiast formuły, które nadają jej pewien kształt, rodzą sprawiedliwość konkretną. Badacz pisze, że „nasza definicja sprawiedliwości jest formalna, bo nie określa kategorii, które są istotne dla stosowania sprawiedliwości w praktyce" ${ }^{29}$.

23 Tamże, s. 112.

24 J. Kiereś-Łach, Filozofia..., s. 60.

25 Tamże, s. 61.

26 Tamże.

27 Ch. Perelman, O sprawiedliwości..., s. 38.

28 S. Tkacz, Rozumienie sprawiedliwości..., s. 8: „koncepcję sprawiedliwości formalnej, zgodnie z którą osoby należące do tej samej kategorii istotnej powinny być traktowane jednakowo".

29 Ch. Perelman, O sprawiedliwości..., s. 38. 
Prawidłem Perelmana ${ }^{30}$ i cechą które - według Ossowskiej - łączy wszystkie koncepcje, jest „[...] czysto formalny postulat żądający traktowania w ten sam sposób istot należących do tej samej kategorii zasadniczej. Ten postulat można by traktować jako pozytywny odpowiednik zasady równej miary, którą zaproponował logik, filozof i badacz zagadnienia sprawiedliwości Kazimierz Ajdukiewicz. Ową zasadę równej miary uważa za rdzeń poczucia sprawiedliwości i formułuje: "nikomu nie należy się nic z tego tylko tytułu, że to właśnie on a nie kto inny". Wyraz "nikomu» dotyczy, oczywiście, tych, których zaliczono do tej samej (mówiąc językiem Ch. Perelmana) kategorii zasadniczej. [...] Czasem idzie tu naprawdę o wszystkich ludzi, kiedy indziej o jakąś grupę, najczęściej uprzywilejowaną"31.

Sześć formuł sprawiedliwości Perelmana, łączy między innymi podobna budowa gramatyczna. Wszystkie koncepcje ujęte są hasłowo. Rozpoczyna je powtarzający się na początku zaimek upowszechniający: „każdemu”, następnie autor wymienia, co lub według kogo i czego ma przypadać lub być przydzielane. Koncepcje sprawiedliwości konkretnej, o których mowa, a które Perelman uważa za najpowszechniejsze ${ }^{32}$ to:

1. Każdemu to samo (fr. à chacun la même chose);

2. Każdemu według jego zasług (fr. à chacun selon ses mérites);

3. Każdemu według jego dzieł (fr. à chacun selon ses ouvres) ) $^{33}$;

4. Każdemu według jego potrzeb (fr. à chacun selon ses besoins) ${ }^{34}$;

5. Każdemu według jego pozycji / stanu (fr. à chacun selon son rang) ${ }^{35}$;

6. Każdemu według tego, co przyznaje mu prawo (fr. à chacun selon ce que la loi lui attribue).

Kogo należy rozumieć jako „każdego”? „Każdy” oznacza wszystkie jednostki w wybranej kategorii istotnej. Pisząc „każdy”, Perelman dookreśla, że chodzi (między innymi) o osoby działające, społeczeństwo, każdą istotę ludzką, różne kategorie ludzi, każdego człowieka itd. ${ }^{36}$; „(...) A to, że człowiek jest osobą, odróżnia go od wszelkich istot naturalnych" ${ }^{37}$. Powyższe stwierdzenia pozwalają

${ }^{30}$ Tamże, s. 87, niezmienne prawidło to: „wszystkie istoty określonej kategorii mają być traktowane w pewien określony sposób".

${ }^{31}$ M. Ossowska, Ch. Perelman..., s. 124-125; Tkacz zauważa, że sprawiedliwość formalną można wyrażać (obok Perelmanowskiej zasady traktowania jednakowo osób należących do tej samej kategorii istotnej i przytoczonej powyżej formuły „równej miary” Ajdukiewicza) jako maksymę „traktuj podobne przypadki tak samo [...] i traktuj różne przypadki odmiennie”, H. L. A. Hart, Pojęcie prawa, przeł. J. Woleński, Warszawa 1998, s. 216 (cyt. za: S. Tkacz, Rozumienie..., s. 35).

${ }^{32}$ Ch. Perelman, O sprawiedliwości..., s. 22.

${ }^{33}$ M. Ossowska, Ch. Perelman..., s. 124: „każdemu się należy w jakiejś proporcji do jego osiągnięć”.

${ }^{34}$ Fr. besoins w polskim tłumaczeniu występuje też jako: „wymagania”.

${ }^{35}$ Fr. rang w polskim tłumaczeniu występuje też jako: „ranga”.

${ }^{36}$ Ch. Perelman, O sprawiedliwości..., s. 24-27.

${ }^{37}$ E. Stein, Budowa osoby ludzkiej. Wykład z antropologii filozoficznej, przeł. G. Sowiński, Kraków 2015, s. 161: „Patrzę w oczy zwierzęcia - z których coś patrzy ku mnie. [...] jest to niema i uwięziona dusza: uwięziona w sobie, niezdolna cofnąć się w głąb siebie i uchwycić samą siebie, niezdolna \{wyjść\} 
zatem zawęzić przedmiot naszych badań. Zakres słowa „każdy” obejmuje tylko klasę istot ludzkich. W formułach sprawiedliwości Perelmana to słowo dotyczyć będzie nie tylko ustalania sprawiedliwości między pojedynczymi osobami w zakresie grupy ludzi, lecz również między jedną grupą a inną. Biorąc pod uwagę wspólną cechę podmiotów, między które będziemy rozdzielać dobra lub od których będziemy żądać świadczeń, nazywamy te podmioty osobami należącymi „do tej samej kategorii istotnej” ${ }^{38}$. Perelman, zwraca uwagę, że jednostki ludzkie łączy równa miara, czyli swego rodzaju tożsamość, która nie zachodzi na przykład między człowiekiem a rośliną. Pomiędzy podmiotami nietożsamymi niemożliwe jest zastosowanie reguły sprawiedliwości ${ }^{39}$, a zatem badania Perelmana nie będą dotyczyć tego rodzaju relacji. Autor uściśla: „człowiek uznał we wszystkich istotach do siebie podobnych swoich bliźnich, dlatego, że pojęcie ludzkości skrystalizowało się powoli" ${ }^{40}$.

Każda z formuł sprawiedliwości może odnosić się do różnych grup ludzkich, „może być interpretowana w różny sposób i mieć ogromną liczbę wariantów” Filozof zawęża określenie „każdy” do osób „należących do tej samej kategorii istotnej" 42 . Możemy zatem mówić o pewnego rodzaju wspólnocie, grupie społecznej, gromadzie ludzkiej itd.

Literatura daje mnogość teorii wykorzystujących powyższe pojęcia, nawiązujące do antropologii filozoficznej, w kontekście spoistości wspólnoty. Nie wdając się w szersze rozważania, przytoczę tu między innymi cechy członków wspólnoty, ich przeświadczenie i społeczny układ sił. Filozof moralności i teorii socjologicznych, Eugène Dupréel, na którego powołuje się Perelman, zauważa, że „społeczeństwo w ogóle, czy też nieokreślone środowisko społeczne, będące

poza siebie i dotrzeć do mnie. Patrzę w oczy człowieka, który swym spojrzeniem mi odpowiada. [...] Jest panem swojej duszy: otwiera bądź zamyka jej wrota. [...] Spojrzenie człowieka mówi. W jego spojrzeniu przygląda mi się czuwające »ja«, które jest panem samego siebie. Mówimy również: »Wolna osoba duchowa«. Być osobą znaczy: być wolną i duchową istotą. \{A to, że\} człowiek jest osobą, odróżnia go od wszelkich istot naturalnych".

${ }^{38}$ Ch. Perelman, O sprawiedliwości..., s. 37.

${ }^{39}$ P. Tisset, Les notions de Droit et de Justice, „Revue de Metaphysique et de Morale” 1930, nr 1, s. 66, cyt. za: Ch. Perelman, O sprawiedliwości..., s. 34-35: „Już Arystoteles zauważył, że między istotami podlegającymi sprawiedliwości musi istnieć pewne podobieństwo. [...] Między jednostkami ludzkimi musi być coś wspólnego - powiada Tisset [...] - dzięki czemu można by ustalić częściową tożsamość wszystkich ludzi i wprowadzić wśród nich sprawiedliwość: tam gdzie nie ma wspólnej miary, a więc tożsamości, nie może być nawet mowy o sprawiedliwości. [...] Nie ma mowy o sprawiedliwości np. w stosunkach między ludźmi a roślinami; pojęcie sprawiedliwości nabrało obecnie szerszego zasięgu i stosuje się do wszystkich ludzi dlatego, że człowiek uznał we wszystkich istotach do siebie podobnych swoich bliźnich, dlatego, że pojęcie ludzkości skrystalizowało się powoli... Zasięg stosowania sprawiedliwości nie jest określony a priori, a więc może ulegać zmianom. Słowo każdy w formule sprawiedliwości może się odnosić do różnych grup ludzkich".

40 Tamże, s. 34-35.

${ }^{41}$ Tamże.

42 Tamże, s. 37. 
bezpośrednim przedmiotem obserwacji socjologa, nie stanowi grupy społecznej jednorodnej, lecz skomplikowany zespół zrzeszeń współistniejących i wzajemnie się przenikających" ${ }^{33}$; „tworzenie się grup społecznych wyraźnie wyodrębnionych i trwałych również zawęża pole działania instynktów społecznych, nie tylko jest okazją do pełnego ich rozwoju" ${ }^{44}$.

\section{Kto, komu i w jaki sposób przyznaje „coś"?}

By zrozumieć uczynki międzyludzkie i rozważyć sprawiedliwość czynu, potrzeba zaangażowania minimum dwóch partnerów. Ajdukiewicz podaje, że "mogą tymi partnerami być dwie osoby fizyczne, [...] jakieś instytucje lub grupy społeczne, które również można nazwać osobami w rozszerzonym sensie" ${ }^{45}$. Przedmiotem takiego rozważania mogą być również działania rządów państw; jak zauważa Friedrich August von Hayek, ekonomista, filozof polityki i badacz zależności między państwem i obywatelem, „problemem dla każdego rządu jest, "kto, co, kiedy i jak otrzymuje»" 46 . Hayek porównuje ten problem do Leninowskiego powiedzenia z początków rządów radzieckich, które wyrażało problem społeczeństwa socjalistycznego: „kto komu? [...] Kto za kogo planuje, kto kim kieruje, i nad kim panuje, kto komu wyznacza jego miejsce w życiu, i za kogo inni będą rozstrzygać, co mu się należy" "47. Hayek pisze, że „te kwestie z konieczności stają się głównymi problemami, o których może decydować tylko najwyższa władza"48. Jednak dalej wprowadza dwa istotne rozróżnienia:

„po pierwsze, można podejmować różne kroki, nie mając możliwości stwierdzenia, w jaki sposób wpłyną one na poszczególne jednostki, co za tym idzie, nie dążyć do takich konkretnych rezultatów. [...] Po drugie, to zakres działalności rządu przesądza o tym, czy wszystko, co dany człowiek kiedykolwiek otrzymuje, zależy od rządu, czy też jego wpływ ogranicza się do tego, by jacyś ludzie otrzymali coś bliżej niesprecyzowanego w sposób nieokreślony i w nieprzewidzianym momencie. Do tego sprowadza się różnica między ustrojem opartym na wolności a reżimem totalitarnym" ${ }^{49}$.

Także Zygmunt Ziembiński, filozof prawa, logik i komentator zagadnienia sprawiedliwości oraz sprawiedliwości społecznej, podjął krytykę formuł

\footnotetext{
43 E. Dupréel, Traktat o moralności, przeł. Z. Glinka, Warszawa 1969, s. 239.

44 Tamże, s. 241.

45 K. Ajdukiewicz, O sprawiedliwości, s. 109-121.

46 F.A. Hayek, Droga do zniewolenia, przeł. K. Gruba i in., Kraków 2009, s. 124.

47 Tamże.

48 Tamże.

49 Tamże.
} 
sprawiedliwości i zauważył, że „poprawnie zbudowana teoria sprawiedliwości powinna opisywać spotykane sposoby pojmowania, metody badania, jak i rozstrzygania problemów oraz twierdzenia o aprobacie czy dezaprobacie określonych formuł sprawiedliwości przez określone kręgi społeczeństwa, itd”"50. Twierdzi on, że „nie tylko formułuje się podstawowe pojęcia i wypowiada określone twierdzenia o sprawiedliwości, lecz także propaguje się określony sposób rozstrzygania problemów sprawiedliwości, argumentując na jego rzecz i poddając krytyce rozstrzygnięcia oparte na odmiennym wartościowaniu zjawisk" ${ }^{51}$. Jak pisze w innym miejscu: „rzecz w tym, aby doktryny moralne nawiązujące do określonych teorii życia społecznego były otwarte na dyskusję i na krytykę przyjmowanych w nich założeń intelektualnych" ${ }_{52}$.

Ziembiński stawia pytanie, komu sprawiedliwość się należy ${ }^{53}$. „Pytanie to może być potraktowane jako element pytania, czy »prawa człowieka« (wolność, uprawnienia, upoważnienia do dokonywania jakichś ważnych czynności o doniosłości publicznej) mają przysługiwać wszystkim, czy jedynie tym, którzy należycie spełniają nałożone na nich obowiązki społeczne" ${ }^{54}$. Uważa on, że grupa podmiotów, co do której stosować będziemy daną formułę, może być ograniczona „do węższego kręgu osób” ${ }^{55}$, a kryteria, przez które będziemy dokonywać tego zawężenia, mogą być bardzo różne, między innymi: „stosunek do dziecka poczętego”, „głęboko upośledzone jednostki ludzkie”, „etnocentryzm”, „jednostki ludzkie w stanach ekstremalnych", „jednostki niesprawiedliwe”, „jednostki pracowite”, sprawiedliwość „między grupami jednostek”, „między narodami”, „między pokoleniami” ${ }_{56}$ itd. Problematyka każdego zawężenia jest na swój sposób zawiła. Jak pisze Ziembiński, „są to problemy wymagające odrębnej monografii” ${ }^{57}$.

Kwestia odmierzania sprawiedliwości wymaga zatem reguł czy też zasad, którymi będziemy się kierować. Jeżeli w sytuacjach konfliktu ludzie zwracają się do sędziego, niczym do Arystotelesowskiego pośrednika, który ma za zadanie odmierzyć każdemu, komu trzeba, jego należność, to - zdaniem Ziembińskiego - odpowiednio wyważone i doprecyzowane formuły Perelmana, moga służyć w takim przypadku jedynie jako pewne ogólne wskazówki dla organu wydającego decyzję w danej sprawie ${ }^{58}$.

50 Z. Ziembiński, Sprawiedliwość..., s. 43.

51 Tamże.

52 Tamże, s. 46.

53 Zob. Z. Ziembiński, O pojmowaniu sprawiedliwości, Lublin 1992, s. 45-55.

54 Tamże, s. 48.

55 Tamże, s. 50.

56 Tamże, s. 45-55.

57 Tamże, s. 54.

58 Tamże, s. 33: „hasłowo zwerbalizowane formuły sprawiedliwości w ich radykalnym, jednostronnym ujęciu nie są możliwe do stosowania w praktyce życia społecznego. Faktycznie akceptowane są i stosowane nie formuły proste, lecz formuły złożone, łączące elementy zaczerpnięte z różnych 
Ziembiński zauważa problem wysuwania „przez poszczególne kategorie i grupy członków społeczeństwa jednoaspektowych formuł sprawiedliwości, a odsuwanie na daleki plan innych podobnych, co się odbywa z rozdzieraniem szat, tak że preferowany przez jakąś grupę element składowy »sprawiedliwości społecznej « jest niedoceniany" ${ }_{59}$. Jego zdaniem rozwiązaniem tego problemu jest "uzgodnienie systemu wartości pomiędzy rządzącymi oraz rządzonymi”"60, które nazywa „konsensem”. Jak zaznacza, „wymaga on [konsens - P.Ś.] jednak osiągnięcia w sposób przynajmniej w jakimś stopniu zinstytucjonalizowany i ustabilizowany, aby dyskusje nad tym, co sprawiedliwe, a co niesprawiedliwe, nie wybuchały co chwila od nowa. [...] Konsens musi zresztą dotyczyć nie tylko formuł odnoszących się do świetlanej przyszłości, ale też formuł dotyczących okresu przejściowego, zazwyczaj bardzo zawiłych i trudnych do doprecyzowania" ${ }^{\circ}$.

Zatem „w toku analizy obraz merytarnych formuł sprawiedliwości [tj. określających podstawę rozdziału dóbr, biorąc pod uwagę przy tym jakiś czynnik leżący po stronie podmiotu, np. zasługi - P.Ś.], staje się coraz bardziej złożony i rysuje się wiele problemów, których nie można zbyć przez powołanie się na jakieś prosto ujęte hasła sprawiedliwości. Konieczne staje się rozważenie, co się komu ze względu na co należy. Łączy się więc ze sobą pewne prostsze formuły sprawiedliwości, domagające się na przykład współmierności nie tylko w ramach sprawiedliwości wyrównawczej między jednostkami, ale również między tym, co jednostka świadczy dla jakiegoś dobra wspólnego i co się jej w zamian sprawiedliwie należy" ${ }^{\prime 2}$.

Natomiast „od prawników, którzy rozstrzygają konkretne problemy, czy od tych, którzy projektują ustawodawstwo w odwołaniu się do określonej formuły sprawiedliwości, trudno się spodziewać traktatów moralnych. Można jednak starać się o to, by choćby w zarysie ujawniali swoje rozumowanie w tych sprawach, ponieważ byłoby to czynnikiem pobudzającym do refleksji w tej dziedzinie" ${ }^{63}$. Uważam, podobnie jak Ziembiński, że „rozstrzygnięcia z obszaru sprawiedliwości powinny być dokonywane imperio rationis, a nie tylko ratione imperii”" ${ }^{4}$, to jest $\mathrm{z}$ należytym rozeznaniem i właściwym argumentowaniem.

\footnotetext{
formuł prostych, przy czym uzgodnienie roli i wagi tych elementów w kształtowaniu formuły złożonej sprawia wiele trudności i daje okazję do licznych sporów, co w konsekwencji utrudnia zgodne zakwalifikowanie jakiegoś czynu jako sprawiedliwego czy niesprawiedliwego".

${ }^{59}$ Z. Ziembiński, O pojmowaniu..., s. 160.

60 Tamże.

${ }^{61}$ Tamże.

${ }^{62}$ Z. Ziembiński, Sprawiedliwośćc..., s. 30.

63 Tamże, s. 51.

64 Tamże.
} 


\section{Poszukiwanie prawości sędziego}

Analizując teoretycznie pojęcie sprawiedliwości, Perelman zwraca uwagę, że akt sprawiedliwy dąży do równego odmierzania, prawidło sprawiedliwe jest negacją arbitralności, zaś człowiek sprawiedliwy jest zaprzeczeniem człowieka okrutnego. Akt sprawiedliwy musi być zatem zgodny z właściwie użytym prawidłem, natomiast prawidło sprawiedliwe musi odnosić się do każdej jednostki spośród danej kategorii istotnej. Sędzia sprawiedliwy sądzi istoty, które zaliczają się do tej samej kategorii istotnej65. Powyższe rozważania ujawniają charakter statyczny, a nie dynamiczny koncepcji sprawiedliwości. Perelman zwraca jednak uwagę, że „prawo nie reguluje wszystkiego: nie jest w stanie wszystkiego przewidzieć. W wyjątkowych sytuacjach, w przypadku wystąpienia tzw. siły wyższej, ścisłe zastosowanie prawa może stanąć w sprzeczności ze zdrowym rozsądkiem i zasadą słuszności. Sędzia musi więc uczynić prawo elastycznym, aby stało się możliwe do przyjęcia" ${ }^{66}$.

Tym samym Perelman postuluje, aby w przypadkach, w których prawo nie wystarcza do wymierzenia sprawiedliwości, dopuścić do podjęcia decyzji zakładaną prawość sędziego rozumianą jako podporę sprawiedliwości ${ }^{67}$. Dalej podkreśla, że „nie potrzeba sędziego, gdy reguły doprowadzą każdego do tego samego rozstrzygnięcia (przy założeniu, że nie popełnia się błędów), a istnieją poprawne reguły rozumowania z niespornych przesłanek. Potrzebujemy sędziego, gdy reguły te są wieloznaczne, gdy rozumowanie prowadzi do konkluzji, lecz uzasadnia decyzję" ${ }^{\prime \prime}$.

Już Arystoteles dostrzegł ten problem, gdy chodzi o ocenę słuszności danego czynu w oparciu o prawo ogólne (podobnie św. Tomasz z Akwinu; w powyższym wypadku należy ufać bezstronności sędziego) ${ }^{69}$. W tym miejscu można

${ }^{65}$ Perelman odwołuje się do posągu Sprawiedliwości (posągu greckiej bogini Temidy; rzymska Iustitia przedstawiana była bez przepaski na oczach) jako do alegorii sędziego, który sądzi bezstronnie wszystkich, co „do których stosuje się to samo prawidło, [...] bez względu na konsekwencje. [...] Dura lex, sed lex". Zob. Ch. Perelman, O sprawiedliwości..., s. 117.

Interesującą postacią, która również przyświeca zawodom prawniczym, jest urodzony w XIII wieku we Francji św. Iwo Hélory - patron m.in. sędziów, adwokatów, sprawiedliwości i uczciwego prawa. Zob. G. Maroń, Święci patroni prawników, Rzeszów 2011, s. 43 i 55: „Św. Iwo był zaangażowany w obronę zasad sprawiedliwości i słuszności, troszczył się o poszanowanie podstawowych praw człowieka, o szacunek dla jego podstawowej i transcendentalnej godności oraz o ochronę, którą prawo musi gwarantować. [...] pozostaje głosem sprawiedliwości, służącym pojednaniu i pokojowi w celu stworzenia nowych relacji pomiędzy ludźmi i wspólnotami oraz zbudowaniu bardziej sprawiedliwego społeczeństwa”.

${ }^{66}$ Ch. Perelman, Logika prawnicza. Nowa Retoryka, przeł. T. Pajor, Warszawa 1984, s. 230; cyt. za: K. Zeidler, B. Tecław, Perelman, Sopot 2018, s. 140.

${ }^{67}$ Ch. Perelman, O sprawiedliwości..., s. 64.

${ }^{68}$ Tamże, s. 141; cyt. za: Ch. Perelman: Justice, Law and Argument: Essays on Moral and Legal Reasoning. Dordrecht 1980, s. 143-144.

${ }^{69}$ Por. Arystoteles, Etyka nikomachejska, przeł. D. Gromska, Warszawa 2007, s. 170 i nast. 
postawić pytania o to, czym jest prawość sędziego oraz które sytuacje są tymi wyjątkowymi, uzasadniającymi sięgnięcie do indywidualnej prawości sędziego. Udzielenie wyczerpującej odpowiedzi wymagałoby jednak znacznie szerszej formy niż artykuł.

Wśród sześciu formuł sprawiedliwości Perelmana ostatnia z nich różni się od pozostałych tym, że osoba stosująca prawo (na przykład sędzia) nie ma możliwości wyboru - musi trzymać się ustalonych norm, narzuconych kategorii istotnych czy też ustalonego porządku. Jak zauważa sam Perelman, jest to najistotniejsza „różnica między moralną a prawną koncepcją sprawiedliwości”70. Podkreśla on ponadto, że „trzeba wiedzieć, w jakim stosunku dane fakty pozostają do określonego systemu prawnego i jak należy je zakwalifikować”71. Formuła ta uwypukla kwestię pewnego subiektywnego spojrzenia sędziego na rzeczywistość (nawet tego o nieskazitelnej bezstronności). Niebezpieczeństwo polega na tym, że „sędzia może stworzyć inny obraz rzeczywistości i wyprowadzić z niego inne zastosowanie norm prawnych. Jurysprudencja zaś może nawet posunąć się jeszcze dalej w interpretacji faktów. Od niej właśnie zależy definicja wszystkich pojęć mglistych, wszystkich niejasnych wyrażeń prawnych"72. Perelman stawia pod znakiem zapytania spójność kategorii, jakie ustanowił prawodawca, z kategoriami uznanymi przez masy. Zaznacza również, że prawo pozytywne nigdy nie powinno „znaleźć się w sprzeczności ze sprawiedliwością formalną, bo prawo to określa jedynie kategorie istotne, o których mówi sprawiedliwość formalna, a bez określenia ich stosowanie sprawiedliwości jest w ogóle niemożliwe"73.

Perelman zauważa, że mimo prostej formuły, prawidłem można manipulować, tak że czyn formalnie niesprawiedliwy uznamy za usprawiedliwiony (poprzez pokrętną argumentację). By ustrzec się arbitralności (to jest: czegoś, co „nie będąc koniecznym następstwem prawa teoretycznego, nie daje się niczym usprawiedliwić"74), która implikuje nierówność, a w konsekwencji pustość formuły, należy przestrzegać, by dane prawidło pozostawało zgodne z zasadami danego systemu i było racjonalne, a nie emocjonalne.

W celu uzasadnienia praw normatywnych, Perelman nadmienia, że zawsze należy sięgnąć do ogólniejszego prawa, a „na szczycie takiego systemu znajdują się najogólniejsze prawa nauki, które pozwalają wyjaśnić wszystkie inne"75. W rozważaniach filozofa zauważam dwa bardzo interesujące ustalenia: z jednej strony możliwe jest dalsze rozwijanie nauki dzięki odkrywaniu zasad

\footnotetext{
70 Ch. Perelman, O sprawiedliwości..., s. 50 i nast.

71 Tamże.

72 Tamże, s. 51 i nast.

73 Tamże, s. 54.

74 Tamże, s. 70; cyt. za: J. Kiereś-Łach, Filozofia..., s. 64.

75 Tamże, s. 65.
} 
coraz to ogólniejszych; z drugiej zaś „każde wyjaśnienie jest zawsze względne i niedokończone"76.

\section{Praktyczne zastosowania koncepcji sprawiedliwości Perelmana}

Zaproponowana przez Perelmana koncepcja sprawiedliwości formalnej implikuje konieczność dalszych rozważań. Jak trafnie zauważa Kiereś-Łach, „poczucie sprawiedliwości (fr. sens de la justice) często uwzględnia jednocześnie wiele cech istotnych, które z kolei tworzą niedające się ze sobą pogodzić kategorie istotne" ${ }^{77}$, natomiast formuły sprawiedliwości konkretnej różnią się w sposobie określania danego prawidła. Perelman dodaje, że „stosowane przez nas prawidło musi mieć strukturę logiczną o postaci: »wszystkie M powinny być P lub żadne $\mathrm{M}$ nie powinno być $\mathrm{P}$, a więc musi być prawidłem uniwersalnym o charakterze pozytywnym lub negatywnym «"78. Filozof wprowadza zatem wnioskowanie, które nazywa sylogizmem imperatywnym (różniącym się od klasycznego sylogizmu). Polega ono: po pierwsze, na przestrzeganiu prawidła sprawiedliwości formalnej („nakazującego traktować w pewien sposób wszystkie istoty należące do określonej kategorii" 79 ), które jest przesłanką większą owego sylogizmu; po drugie, na wyznaczeniu mniejszej przesłanki sylogizmu, to jest uznaniu, że dana osoba podpada pod określoną kategorię; po trzecie, na utrzymaniu w konkluzji sylogizmu czynu sprawiedliwego - „innymi słowy, sprawiedliwość jest zgodna z rozumowaniem, ponieważ wniosek wynika logicznie z przesłanek" ${ }^{80}$. Proces ten ma charakter analityczny i nie wyjaśnia przypadków, w których badana osoba nie należy do żadnej kategorii lub jest jedyna w swojej grupie. Nie uwzględnia także sytuacji, w których nie sposób przeprowadzić rozumowania na podstawie powyższych założeń (np. z powodu zawiłości danej sprawy).

Podkreślam mimo wszystko, że koncepcja formuł Perelmana nie jest bezużyteczna. Prawnicy korzystają z zaproponowanych przez autora pojęć - jako przykład zaprezentuję orzecznictwo Trybunału Konstytucyjnego, które nawiązuje do teorii tego badacza zarówno wprost ${ }^{81}$, jak i przez posługiwanie się

76 Tamże.

77 J. Kiereś-Łach, Filozofia..., s. 56.

78 Ch. Perelman, O sprawiedliwości..., s. 57, cyt. za: J. Kiereś-Łach, Filozofia..., s. 56 i nast.

79 Tamże.

80 J. Kiereś-Łach, Filozofia..., s. 60 i nast, autorka rekonstruuje taki przykład:

„(P1) Należy udzielać pomocy materialnej ludziom ubogim.

(P2) X jest osobą ubogą.

(W) Należy udzielić pomocy materialnej osobie X”.

81 Zob. Orzeczenie Trybunału Konstytucyjnego z dnia 22 sierpnia 1990 r., K 7/90. W jego uzasadnieniu powołano się na poglądy Perelmana. 
następującym aparatem pojęciowym: wspólna cecha istotna ${ }^{82}$; przyznawanie jednakowych praw podmiotom odznaczającym się tą samą cechą istotną ${ }^{83}$; przynależność do określonej grupy ludzi ${ }^{84}$; „identyczne traktowanie podmiotów znajdujących się w takiej samej lub zbliżonej sytuacji" ${ }^{85}$.

Trybunał w przeważającej mierze nie korzysta $\mathrm{z}$ formuł Perelmana dosłownie lub wykorzystuje więcej niż jedną formułę sprawiedliwości konkretnej (Perelman nazywa to zjawisko „antynomią sprawiedliwości”). Tę sytuację można zaobserwować w orzeczeniu, w którym Trybunał wymiennie posłużył się formułami „każdemu według jego zasług” oraz „każdemu według jego pracy”" Często konkretna formuła zostaje „zarezerwowana” dla danej dziedziny prawa, np.: „każdemu według jego dzieł”. Trybunał stosuje ją w celu wyznaczenia „sprawiedliwego związku między pracą a płacą" ${ }^{87}$. W tym orzeczeniu skład sędziowski bierze pod uwagę rozmaite czynniki i precyzuje, o jakie dzieła chodzi. Natomiast formuła „każdemu według jego potrzeb” zwana jest też przez Trybunał „socjalną zasadą podziału”"s8, ponieważ wykorzystuje się ją w celu realizacji uzasadnionych potrzeb „obywateli, którzy nie mogą z przyczyn obiektywnych samodzielnie zaspokoić swoich niezbędnych potrzeb życiowych"89.

Wspomniane orzecznictwo Trybunału Konstytucyjnego nasuwa wniosek, że pozornie jednoaspektowe, radykalne i hasłowo zwerbalizowane formuły w praktyce ujawniają swoją złożoność. Jeśli zakładamy, że sprawiedliwość formalna nie może być nic nieznaczącą formułą, to arbitralność musi zostać (na tyle, na ile się da), wyeliminowana z prawideł, dzięki którym stosowana będzie sprawiedliwość.

Zastosowanie sprawiedliwości jest dokonaniem pewnej operacji, w której udział bierze również czynnik uczuciowy. Idea sprawiedliwości jest wewnętrznie połączona składnikiem idei równości. Prawidło staje się arbitralne, gdy jest bezzasadne. System sprawiedliwości to ciąły dialog, który jest zależny od innych wartości. Wartość moralna jest podstawą tego systemu i taka wartość (lub wartości), rozwijana formalnie przez ten system, musi nas zadowolić. Zgadzam się z Perelmanem, że „jedynie naiwny racjonalizm sądzi, że rozum jest zdolny do znalezienia prawd oczywistych i wartości niezaprzeczalnych. [...] Czyn jest sprawiedliwy w odniesieniu do prawidła, prawidło jest sprawiedliwe w odnie-

82 Orzeczenie TK z dnia 14 kwietnia 2015 r., P 45/12.

83 Orzeczenie TK z dnia 22 maja 2013 r., P 37/12.

${ }^{84}$ Orzeczenie TK z dnia 5 listopada 1986 r., U 5/86; cyt. za: S. Tkacz, O zintegrowanej koncepcji zasad prawa w polskim prawoznawstwie, Toruń 2015, s. 117.

${ }^{85}$ Orzeczenie TK z dnia 22 maja 2013 r., P 37/12.

86 Orzeczenie TK z dnia 30 listopada 1988 r., K 1/88.

87 Orzeczenie TK z dnia 9 marca 1988 r., U 7/87; cyt. za: S. Tkacz: Rozumienie..., s. 108.

88 Orzeczenie TK z dnia 9 maja 1989 r., Kw 1/89; cyt. za: S. Tkacz: Rozumienie..., s. 100 i nast.

${ }^{89}$ Orzeczenie TK z dnia 6 października 2015 r., SK 19/14. 
sieniu do wartości, które służą za podstawę danego systemu normatywnego. [...] Sprawiedliwość absolutna, całkowicie oparta na rozumie nie istnieje" ${ }^{90}$.

Perelman trafnie zauważa, że nieuniknioną pułapką sprawiedliwości teoretycznej i statycznej (mimo iż obie porządkują w pewnym stopniu życie społeczne) jest „zawsze jakiś określony redukcjonizm i absolutyzacja jakiejś cechy uznanej za istotną, a ostatecznie ekskluzywizm i totalitaryzm społeczny"91. Sprawiedliwość istot ludzkich albo jest wrodzona, albo dąży do niej rozum praktyczny jednostki. Mimo że w swoich poszukiwaniach Perelman przywołuje mądrość „klasyków filozofii realistycznej”92 (Arystotelesa i św. Tomasza z Akwinu) celem wypracowania „pewnej wspólnej płaszczyzny rozważań dla wpływowych koncepcji sprawiedliwości"93, to i tak zauważa problemy, z którymi musi się zmierzyć sumienie ${ }^{94}$.

Zgadzam się również z tym, że „ten, kto miłuje sprawiedliwość, nie może się zadowalać ścisłym i ślepym stosowaniem prawideł wynikających z systemu normatywnego: pamięta o podstawie systemu, który nie jest i nie może być doskonałym. Nie zapomni, że obok wartości uznawanych przezeń istnieją wartości inne, dla których ludzie gotowi są na wyrzeczenia i poświęcenia, że rewizja wartości jest zawsze możliwa"95.

Odrębnego rozważenia wymaga jednak zbadanie granic wyżej wymienionej rewizji wartości konstruujących sprawiedliwość, szczególnie gdy dokonują jej osoby wykształcone do zajmowania się oceną zachowania innych i przyznawania im statusu dobra lub zła.

Dociekania Perelmana i prace komentatorów jego myśli dowodzą, że badacz wspomina o potrzebie reakcji sędziego w wypadku wieloznaczności reguł. Nie precyzuje jednak, czym jest „prawość sędziego”: czy jest to indywidualne odczucie bazujące na własnym spostrzeganiu (doświadczeniu życiowym), czy raczej namysł wsparty o literę prawa (jego interpretacja). Perelman nie rozważa szerzej, czy rzeczona prawość jest nieomylna i czy sędzia zawsze podejmie decyzję w oparciu właśnie o nią, a nie o inną wartość, cechę charakteru lub inne czynniki. Podkreśla jedynie, że niebezpieczeństwem dowolnego działania sędziego może być subiektywizm, a także odmienny obraz postrzeganej przez niego rzeczywistości. Idzie za tym błędne lub złe zastosowanie norm prawa.

${ }^{90}$ Ch. Perelman, O sprawiedliwości..., s. 106 i nast.

${ }^{91}$ Ch. Perelman, O sprawiedliwości..., s. 30, 34, 116, 120, 123, 126, 130, 133; cyt. za: J. Kiereś-Łach, Filozofia..., s. 149.

92 J. Kiereś-Łach, Filozofia..., s. 149 i nast.

93 Tamże.

94 „[Zygmunt Ziembiński] bardzo często mówił: Sumienia trzeba używać”. Zob.: Wybitne Postacie Uniwersytetu \#4 - prof. Zygmunt Ziembiński: wypowiedź S. Wronkowska-Jaśkiewicz, online: https:// www.youtube.com/watch? $\mathrm{v}=\mathrm{bVuEKtu}-\mathrm{taQ}$ [dostęp: 26 marca 2019].

${ }_{95}$ Ch. Perelman, O sprawiedliwości..., s. 109 i nast. 
Nie zawsze jest zresztą tak, że złe prawo krępuje sędziego przed wydaniem słusznej decyzji. Ścisłe trzymanie się litery prawa może jednak prowadzić do wypaczeń, bezduszności czy totalitaryzmu, natomiast pozostawienie nadmiernej przestrzeni dla „prawości sędziego” może implikować jego samowolę, brak oparcia decyzji w obowiązujących przepisach, a nawet działanie anarchiczne czy despotyczne. Pragnę zwrócić uwagę, jak istotne jest wyważenie między skrajnościami. Każdy sędzia powinien posiadać swoją prawość i sumienie, lecz nie powinien z nich korzystać bez namysłu i w dowolnej sytuacji. Dookreślenie granic działania „prawości sędziego” i tego, kiedy sędzia może się nią posługiwać, istotnie wpływa na zakres wolności i ograniczeń sądzących, lecz - co istotniejsze - również na wymierzenie sprawiedliwości sądzonym.

\section{Bibliografia}

Ajdukiewicz K., O sprawiedliwości, „Kultura i Wychowanie” 1939, nr 2.

Arystoteles, Etyka nikomachejska, przeł. D. Gromska, Warszawa 2007.

Biernat S., Rozdział dóbr przez państwo. Uwarunkowania społeczne i konstrukcje prawne, Wrocław 1989.

Dupréel E., Traktat o moralności, przeł. Z. Glinka, Warszawa 1969.

Hart H.L.A., Pojęcie prawa, przeł. J. Woleński, Warszawa 1998.

Hayek F.A., Droga do zniewolenia, przeł. K. Gruba, L. Klyszcz, J. Margasiński, D. Rodziewicz, M. Kuniński, Kraków 2009.

Kelsen, The Metamorphoses of the Idea of Justice, [w]: Interpretations of Modern Legal Philosophies. „New York Times" 1 stycznia 1947.

Kiereś-Łach J., Filozofia i retoryka. Kontekst myślowy „"nowej retoryki" Chaïma Perelmana, Lublin 2015. Maroń G., Święci patroni prawników. Rzeszów 2011.

Ossowska M., Ch. Perelman - O sprawiedliwości (De la justice), „Ruch Filozoficzny"1948, nr 3-4.

Perelman Ch., Justice, Law and Argument: Essays on Moral and Legal Reasoning, Dordrecht 1980.

Perelman Ch., Logika prawnicza. Nowa Retoryka, przeł. T. Pajor, Warszawa 1984.

Perelman Ch., O sprawiedliwości, przeł. W. Bieńkowska, Warszawa 1959.

Stein E., Budowa osoby ludzkiej. Wykład z antropologii filozoficznej, przeł. G. Sowiński, Kraków 2015. Tisset P., Les notions de Droit et de Justice, „Revue de Metaphysique et de Morale" 1930, nr 1.

Tkacz S., O zintegrowanej koncepcji zasad prawa w polskim prawoznawstwie, Toruń 2015.

Tkacz S., Rozumienie sprawiedliwości w orzecznictwie Trybunału Konstytucyjnego, Katowice 2003. Zeidler K., Tecław B., Perelman, Sopot 2018.

Ziembiński Z., O pojmowaniu sprawiedliwości, Lublin 1992.

Ziembiński Z., Sprawiedliwość społeczna jako pojęcie prawne, Warszawa 1996.

\section{Źródła internetowe:}

Doroszewski W. Słownik Języka Polskiego, online: https://sjp.pwn.pl/doroszewski/prawosc;5481 278.html [dostęp: 6 sierpnia 2020].

Wybitne Postacie Uniwersytetu \#4 - prof. Zygmunt Ziembiński, online: https://www.youtube.com/ watch?v=bVuEKtu-taQ [dostęp: 26 marca 2019]. 


\section{Orzecznictwo:}

Orzeczenie TK z dnia 5 listopada 1986 r., U 5/86.

Orzeczenie TK z dnia 9 marca 1988 r., U 7/87.

Orzeczenie TK z dnia 30 listopada 1988 r., K 1/88.

Orzeczenie TK z dnia 9 maja 1989 r., Kw 1/89.

Orzeczenie TK z dnia 22 sierpnia 1990 r. sygn. K 7/90.

Orzeczenie TK z dnia 22 maja 2013 r., P 37/12.

Orzeczenie TK z dnia 14 kwietnia 2015 r., P 45/12.

Orzeczenie TK z dnia 6 października 2015 r., SK 19/14.

\section{Wpływ koncepcji sprawiedliwości Chaima Perelmana na dokonywane dzisiaj rozstrzygnięcia Trybunału Konstytucyjnego}

\section{Streszczenie}

Artykuł dotyczy koncepcji sprawiedliwości zaproponowanej przez Chaima Perelmana w 1945 roku, stanowiącej kontynuację poglądów Arystotelesa oraz św. Tomasza z Akwinu, jednak pozbawionej ładunku emocjonalnego, który niesie za sobą to pojęcie. Perelman ujmuje swoją tezę w sześć hasłowych formuł sprawiedliwości. Podstawą korzystania z zaproponowanych formuł jest nakaz, mający urzeczywistnić czyn sprawiedliwy, tj. prawidło postulujące jednakowe traktowanie osoby należące do tej samej kategorii istotnej. Autor uwzględnia również rozważania dotyczące tego kto, komu i w jaki sposób ma rozdzielać to, co należne. Perelman zauważa, że stosowanie formuł jest względne i niemożliwe na sposób matematyczny, co prowadzi do wniosku, że rozstrzygnięcie wydawanej decyzji należy pozostawić prawości sędziego. Niebezpieczeństwo stosowania sprawiedliwości w tej formie polega na subiektywnym postrzeganiu rzeczywistości, a przez to na możliwości manipulacji formułami przy ich używaniu.

Słowa kluczowe: Chaim Perelman, teoria sprawiedliwości, formuły sprawiedliwości, sprawiedliwość, prawość, orzecznictwo Trybunału Konstytucyjnego

\section{The impact of Chaim Perelman's conception of justice on today's Constitutional Court decisions}

\section{Summary}

The article discusses Chaim Perelman's conception of justice proposed in 1945. His concept is a continuation of Aristotle's and St. Thomas Aquinas's views, however, it rejects emotional load and formulates a theory through six keyword terms instead. The core foundation of using proposed formulas is the order to treat people that belong to the same social category equally, and this warrant is crucial to act rightly. The article includes thoughts on who, to whom and in which way should distribute what is someone's due. Perelman notices that using these formulas is relative and mathematically impossible, what leads him to the conclusion that the final decision should depend on the judge's righteousness. There is a risk of applying justice in such a form as it consists of subjective perception of reality that creates room for manipulation.

Keywords: Chaim Perelman, theory of justice, formulas of justice, justice, righteousness, decision of Constitutional Court 